\title{
Contextual Challenges for Crisis Support in the Immediate Aftermath of Major Incidents in the UK
}

\author{
Howard Davis
}

Dr Howard Davis is a Programme Leader and Senior Lecturer in Criminology at Edge Hill University, Lancashire. His social work career included work on the Liverpool Social Services Hillsborough Disaster Team from 1989 to 1993 and six years as an HIV Specialist Social Worker. This article draws upon literature and policy review and upon primary fieldwork into the performance of crisis support in a large local authority. Case studies examined the work of crisis support in three declared major incidents. This formed the basis of a successful Ph.D. thesis and was not supported by external funding.

Correspondence to Dr Howard Davis, Senior Lecturer in Criminology, Department of Law and Criminology, Edge Hill University, St Helens Road, Ormskirk, Lancashire, L39 4QP. E-mail: davish@edgehill.ac.uk

\begin{abstract}
Crisis support teams guide survivors and bereaved through the traumatic first hours and days after disaster. Comprised largely of volunteer social workers, they focus on providing practical, pragmatic support: 'orienting', rather than 'counselling' service users. This article examines the generally unacknowledged contextual challenges of crisis support work in the UK. In time-compressed circumstances, making sense of 'major incidents' requires imaginative and reflexive assessment. First, incidents sit within a potentially wide variety of interrelated dimensions, generating demands across geographical, jurisdictional and organisational boundaries. Second, crisis response occurs within processes of 'sense-making' that often involve controversy and social conflict. Third, intra and inter-organisational factors may pose significant difficulties for crisis support responders. Notwithstanding an overdue official recognition of the 'rights' of disaster victims, other recent developments-within social care, private sector 'customer care' and in policing and security-present under-researched challenges for crisis support teams. It is suggested in conclusion that the role and operation of crisis support teams are overdue for review. Issues pertinent to such review are offered.
\end{abstract}

Keywords: Crisis support, disaster management, organisations, victims

Accepted: December 2010 


\section{Introduction}

Response to disasters may seem removed from social work's everyday concerns. The profession, it may be tempting to think, has enough problems in meeting its 'core' demands to devote resources to such remote contingencies. Yet, when disaster does strike, social workers are usually in the vanguard. 'When people are made vulnerable,' as the Social Work Task Force $(2009 b$, p. 5) notes, 'what happens next matters hugely.' This is as true for overwhelming and unforeseen major emergency as it is for the familiar and the chronic. This article discusses the complex, contextual challenges facing UK local authority Crisis Support Teams (CSTs). UK local authorities have lead responsibility for rehabilitating communities after disaster (HM Government, 2006) with recent reform of emergency arrangements centring on the 2004 Civil Contingencies Act. Drawing on Clarke's (2001) Marchioness Inquiry recommendations, reforms include detailed guidance for responders. It is under these arrangements that CSTs provide structured post-disaster support (HM Government, 2006).

Usually comprising social workers, CSTs work with the bereaved and traumatised after mass-fatality emergencies. This article draws on disaster literature and field research. The latter considered three major incidents and was based upon forty-four interviews and the observation of managerial and operational meetings between 2004 and 2007 (Davis, 2011).

The frequency of negative disaster-victim experiences indicates response problems extending beyond the micro-level. Of course, specific intra/interpersonal, team or departmental dynamics are significant (see, e.g., the impact of management 'types' after Hurricane Katrina (Olejarski and Garnett, 2010)) but they understate broader, contextual factors. Critical analysis requires an appreciation of the potential dysfunction, disequilibrium, overloading and poor integration of institutionalised, complex, interrelated systems. It also requires the understanding that the notion of system failure as an explanatory concept has its limitations. Systems are not simply 'functional working units, free from vested interests, social conflict or power relations' (Scraton, 1995, p. 4). Difficulties for victims can arise precisely as a result of systems functioning as intended or from structured contradictions within or between them. Where multi-agency responses systematically prioritise, say, public order above the interests of victims, or where the orientation of social work has become systematically commodified and instrumentalised to the detriment of service users, it is misleading to think in terms of 'system failures'. Here, the smooth functioning of such systems can undermine the human needs and rights of victims.

CSTs, alongside other public organisations, increasingly operate in 'conditions of "permanent whitewater" that is, social, economic and political 
environments that are fraught with risk and rapid change' (Comfort et al., 2001, p. 144). CSTs, moreover, operate in the most difficult of circumstances: the immediate aftermath of disaster. Time compression generates 'a politics of urgency ... [in which] ... it is the speed of being seen "to do something" that is brought to the fore, not time for reflection and planning' (Medd and Marvin, 2005, p. 44). Miscommunication, misunderstanding and conflict are common. Following brief outlines of the emergence of UK crisis support, the article considers three forms of disaster-related challenge that underpin such difficulties: those arising from the scale, characteristics and location of incidents themselves; those arising from the social contexts of incidents; and those arising from organisational factors. Together, these set the challenges and the environment within which CSTs must act.

\section{Humanitarian response to major incidents in the UK} Historical context

Towards the end of the Cold War, a new 'civil protection' discourse argued that military and paramilitary 'civil defence' lacked the legitimacy, knowledge and flexibility of local civilian responses (Dynes, 1994; Alexander, 2002), fitting neatly with the UK's locally based emergency model (Hills, 1994a). These local arrangements, however, were rudimentary. After the 1966 Aberfan tragedy, the scant welfare presence was augmented by only one additional family caseworker (Johnes, 2000, p. 6). Even twenty years later, 'no Health or Social Services department involved in any [of the major UK disasters between 1985 and 1989] had a plan... for long-term psychosocial response' (Hodgkinson and Stewart, 1991, p. 67).

Things changed in the 1980 s as social workers intervened after a succession of disasters (Hodgkinson and Stewart, 1991; Johnston and Beeson, 1993; Newburn, 1993). The daily response to Lockerbie involved over one hundred social work staff (Dumfries and Galloway, 1989). After Hillsborough, social work teams were established in nine different local authorities (Newburn, 1993). Nonetheless, responsibilities remained unclear and arrangements relied on goodwill (Hills, 1994b). Moreover, evidence accumulated that immediate official responses could exacerbate, rather than mitigate, disaster's impact. Victims were sometimes treated callously, left uniformed or misinformed, and denied appropriate access to the deceased and disaster sites (Coleman et al., 1990; Davis and Scraton, 1997, 1999; Scraton, 1999; North, 2000). After the Marchioness disaster, hands were secretly cut from twenty-five of the dead for fingerprinting (Clarke, 2001). A public inquiry examining the aftermath of the tragedy (Clarke, 2001) and broader review of emergency planning led, through the 2004 Civil 
Contingencies Act, to new duties, structures and guidance. Under the act, adult and children's services departments are still regarded as 'best placed to fulfil the humanitarian assistance function' (HM Government, 2007, p. 20).

\section{Official guidance and crisis support}

People bereaved by disaster face a bewildering array of official interventions and wider attention. Official processes include recovering and identifying the dead, informing relatives, post-mortems, arranging viewings of the deceased, civil and criminal investigations and 'managing' the media. Throughout, guidance affirms, 'care and support ... is crucial in managing the longer-term psychological effects' (HM Government, 2007, p. 36). Local authorities have a duty to recruit and train 'an appropriate number of personnel' for emergency response (HM Government, 2005, p. 52). Some have set up CSTs of 'skilled, vetted, trained and prepared volunteers' ready to respond to emergency (HM Government, 2007, p. 26). Drawn mainly from social services, these teams assist in:

- Explaining procedures and processes, keeping people informed, and letting them know the roles of the agencies involved

- Explaining common reactions to crisis and stress and helping identify where specialist help is required

- 'Signposting' to other support and services available in the community; helping people access these; assisting with form-filling

- Fulfilling a listening role (HM Government, 2007, p. 26).

Crisis work should 'provide practical, pragmatic support in a sympathetic manner, to complement the input of friends and family' (Bisson et al., 2007, p. 1017). Good practice is therefore:

... more [about] orientating than ... treating, [it is about] mapping out for the client the sort of difficulties that might be encountered and the directions from which means to resolve the problems might be found. The goal of crisis counselling is to help the client get their bearings (Scott and Stradling, 1992, Appendix D, emphasis added).

\section{Responding to crisis? Disasters as complex challenges}

If CSTs are to help victims 'get their bearings', they must first get their own. They must make sense of what is happening. 'Major incidents' vary widely across a range of dimensions. There is no single mechanical response. What is required instead is 'a comprehensive view of possible stakeholders and 
definitions of the situation' (Rosenthal et al., 1994, p. 125). The dimensions along which disasters might vary include:

Chronic

Visible

Effects dispersed

Mass fatalities

Many survivors

Many non-local survivors

Many seriously injured

Extensive material damage

Response capacity seriously damaged

Natural 'cause'

System failure as 'cause'

Highly newsworthy

'Blame' a major issue

Victims from marginalised groups

Victims potentially blameworthy

Victims heterogeneous

\begin{tabular}{|c|c|}
\hline$\leftrightarrow$ & Acute \\
\hline$\leftrightarrow$ & Invisible \\
\hline$\leftrightarrow$ & Effects localised \\
\hline$\leftrightarrow$ & No fatalities \\
\hline$\leftrightarrow$ & No survivors \\
\hline$\leftrightarrow$ & Local survivors only \\
\hline 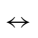 & No injuries \\
\hline$\leftrightarrow$ & No material damage \\
\hline$\leftrightarrow$ & Response capacity undamaged \\
\hline$\leftrightarrow$ & Human 'cause' \\
\hline$\leftrightarrow$ & Individual error as 'cause' \\
\hline & Non-newsworthy \\
\hline$\leftrightarrow$ & 'Blame' not an issue \\
\hline & Victims from high status groups \\
\hline$\leftrightarrow$ & Victims potentially 'idealised' \\
\hline & Victims homogeneous \\
\hline
\end{tabular}

Clearly, the scale, characteristics and location of incidents are important in shaping the problems of the aftermath. Less obviously, incidents' social contexts may be significant. To declare a 'major incident' is easier than to understand its complex specificities. A third set of challenges arises from organisational issues within responses themselves. Here, at inter and intra-organisational levels, a range of factors may mitigate against appropriate response.

\section{Primary challenges: scale, characteristics and location of major incidents}

Scale is clearly important: large incidents usually require large responses. The Lockerbie site was spread across 850 square miles and friends and relatives of victims were spread around the world. Extensive disasters, moreover, may damage response agencies themselves (Horner, 1998; Kendra and Wachtendorf, 2003). Workers themselves may suffer trauma or loss (Dekel and Baum, 2010). Scale, however, does not, of itself, determine response. After one recent incident involving migrants, the Family and Friends Centre (FFC) remained unused. The bereaved, it seemed, were either abroad or reluctant to approach the authorities (Davis, 2011). By contrast, the FFC for another incident involving far fewer fatalities remained busy for several days (Davis, 2011). What was significant was not the number of survivors, but their status as, variously, victims/suspects/migrants/witnesses. So, when, after the first incident, survivors were accommodated at the Survivors Centre, it was not because they were homeless, but because officials did not want them to leave while 
investigations were continuing (Davis, 2011). Thus, the specific characteristics of a disaster and their relationship to organisational perceptions and priorities may be as significant as its scale. Some bereaved may be survivors. Some may be injured or homeless. Body retrieval and identification may be difficult (Hodgkinson and Stewart, 1991; Malkinson, 2003). Military or terrorist attacks may put workers at risk of further violence. The possibilities are wide-ranging.

Location is also important. Disaster sites may be confined or dispersed, rural or urban, accessible or inaccessible. Impact may extend well beyond the site, presenting difficulties for locally oriented services (Smith, 2003). During the 2004 South Asian Tsunami, 30,000 Swedes were in the area and over 500 died (Lennquist, 2004). Relatives may converge from far afield. Disasters involving travellers or migrant communities raise linguistic, cultural, legal and political issues and may evoke scant sympathy (Rosenthal et al., 1994) whilst demanding significant engagement with foreign agencies.

The significance of interrelationships between such dimensions was exemplified by the 2003 French heat-wave disaster, which claimed 15,000 lives. This was not the stereotypical impact disaster of post-9/11 imaginings. Its epicentre was 'everywhere and nowhere', the central target was 'old, isolated people' and the most dangerous place was 'at home, in bed' (Lagadec, 2004, p. 168). Possibly as a consequence, its development was unnoticed, then denied (Lagadec, 2004). It was a warning against conceiving disasters in set 'frames'-frames that may obscure rather than elucidate risk. The challenges of disaster's varied contingencies are not merely organisational. They are challenges of imagination.

\section{Secondary challenges: social contexts, sense-making and blame}

Social contexts are significant for responders. For example, where extreme events are products of violent political conflict, workers do not stand totally apart. Professional values may be compromised and teams may fracture (Ramon, 2004). In civilian disasters, too, contexts shape understandings and choices. Disasters are, in short, political. The concept of 'continuity', discussed below-emphasising the continuing salience of pre-disaster arrangements and conditions at micro and macro levels through impact and aftermath-has tended in official discourse to become associated only with the needs of business resilience. However, at a theoretical level, it implies the continuing (and perhaps even enhanced) significance of preexisting social inequalities and conflict (Green et al., 2007; Tierney, 2007; Henry, 2011).

In this context, the 'threat' of disasters, for some, is that they may act as 'focussing events', 'open[ing] the policy window by dramatically highlighting policy failures' (Birkland, 2004, p. 181): 
Questions are asked that previously went unformulated and the answers can shed floods of light on what everyone previously failed to attend to and took for granted .... Such civic moments can be moments of intense contestation (Lukes, 2005, p. 1).

The stakes can be high over whose 'truth' prevails. Accordingly, the 'causal story' is shaped by public relations specialists (Benoit, 1997; Berger, 1999; Birkland and Nath, 2000; Tyler, 2005). This can be significant for responders in a number of ways. First, time and resources can be squandered. After Hurricane Katrina, "critical time [was] wasted on ... winning the blame game [and] waging a public relations battle' (Davis, 2006, p. 360). Second, some harms may be minimised and others exaggerated amid the politics of blame. Third, victims may be represented negatively, as responsible for their own fates, for those of others or as otherwise deviant. Victims may blame other victims and, where victims (or workers) belong to 'suspect' communities, workers may acquiesce in policies or practices sharply at odds with social work values or turn on each other along national/cultural lines (Ramon, 2004). Blame indeed can pervade post-disaster dynamics and responders may be complicit in scapegoating. After the 1989 Hillsborough disaster, police accused survivors of causing the tragedy through lateness, drunkenness and forcing an egress gate. For good measure, survivors were accused of pick-pocketing and urinating on the dead (Coleman et al., 1990). Conversely, more sophisticated strategies project a 'caring' image. Corporate stakeholders hire premises for victims' meetings, pay for travel, accommodation and counselling, and deploy 'specialist' customer care teams. Deployment of an Incident Care Team after one incident - at a cost of $£ 23,033$ - was hailed by industry peers as a public relations 'bargain' (ATOC Train Crash Debriefing, 18 May 2007).

CSTs will need to account for potential conflict-for example in disseminating information or arranging victims' meetings - and to manage or integrate the activities of corporate responders (see discussion below). Moreover, whatever the broader framing of 'blame', crisis support inevitably becomes intertwined with formal investigation and requires constructive, well-practised partnerships with investigative agencies and others.

\section{Tertiary challenges: organisational issues in effective response}

A third set of challenges derives from relations within and between responder organisations themselves. Organisations need adequate capacity, continuity with pre-incident ways of working, but also flexibility. Between organisations, response must be co-operative. Where these requirements are not met, CSTs can expect problems. 
Intra-organisational factors

\section{Capacity}

Immediate response usually relies on 'spare' capacity. Public organisations are, however, 'enmeshed in an unrelenting search for cost-effectiveness' and many 'have done away with redundancy and back-up facilities' (Rosenthal and Kouzmin, 1996, pp. 121-2), undermining their flexibility to 'relax or eliminate other functions temporarily when needed' (Corbacioglu and Kapucu, 2006, p. 214). Social work is severely stretched. Evidence to the Social Work Task Force (2009b) highlighted vacancy and staff turnover rates significantly above those for other public sector professions. It is a profession subject-even in non-disaster contexts - 'to widespread and longstanding staff shortages that must compromise its ability to deliver quality on the frontline' (Social Work Task Force, 2009b, p. 18). Time for service users, proper supervision and training are all compromised by staff shortages. Problems are exacerbated by inappropriate accommodation, deficient IT and increasing administrative burdens. In this context, CSTs are precariously positioned. One local review, for example, noted the view that 'setting up a team ... was a luxury that could not be afforded [as] staff [were already] hard pressed ... deal[ing] with emergencies already happening' (Smith et al., 2003, p. 525).

\section{Continuity}

'[T]he best predictor of [organisational] behaviour in emergencies is behaviour prior to the emergency' (Dynes, 1994, p. 150). Values, knowledge, priorities, routines and patterns of communication cannot change overnight. Unfamiliarities with bereavement, post-mortems, police or coronial procedure cannot be instantly rectified. Response is best built therefore 'on everyday working practices [and] in an emergency, familiarity and simplicity have virtues all of their own' (Cabinet Office, 2007, p. 7). This raises questions, however, around contemporary 'everyday' social work. Does everyday social work prepare CSTs for disaster response? Critiques increasingly suggest a profession in crisis. Caring has become commodified and subjected to deepening, bureaucratised 'instrumentalism' applied within a tightening plethora of contracts and procedures (Blaug, 1995; Dominelli and Hoogvelt, 1996). On these accounts, social work's primary contemporary concern is with superintending neo-liberal regulatory practices (Carey, 2008a, 2008b; Pollack, 2010). 'At a high emotional cost' (Munro, 2004, p. 1087) focus is fixated on targets and social work is less oriented towards human relationships than to information management (Parton, 2008). For Dominelli and Hoogvelt (1996, p. 46), indeed, '[social 
work's] concern with ... therapeutic work, with ... adaptive responses to life situations has virtually disappeared'. Such concerns are underscored by the Social Work Task Force $(2009 a, 2009 b)$ detailing extensive, deep-rooted problems in contemporary English social work. Over and above the capacity issues noted above, the interim report found that supervision and support are often inadequate. Moreover, enmeshed within a 'disparate group of performance indicators' (Social Work Task Force, 2009b, p. 32), 'social workers themselves struggle to articulate the central role and purpose of the profession' (Social Work Task Force, 2009b, p. 33). The widespread view was that performance indicators measured not quality or outputs, but the rate of completion of processes. 'The overall effect,' the report noted (Social Work Task Force, 2009b, p. 32) 'appears to be a sense of a profession that is, in places, at risk of becoming too mechanised and of being "de-skilled" through an emphasis on compliance rather than judgement'.

If social work has become 'an alienated work task' (Ferguson and Lavalette, 2004, p. 304), this raises an unhappy prospect for crisis support, where congruent, empathic relationships are at a premium. The significance of this is ignored in official emergency discourse. Whilst the Clarke Inquiry (2001) reported disaster social workers refusing tasks due to inexperience in bereavement work, it failed to discuss the issue.

\section{Flexibility}

Continuity must be qualified. Bureaucracies 'work on stable data, formatted problems.... Their basic frameworks of reference are established rules, clear and fixed partitions of areas of competence and levels of responsibility, top-down dynamics, and a programmed time frame' (Lagadec, 2004, p. 162).

Standard procedures, however, do not account for exceptional aspects of crisis - unpredictability, ambiguity and overload (Dynes, 1994; Sellnow et al., 2002). Major incidents undermine linear, centralised administration (Corbacioglu and Kapucu, 2006). Lagadec (2004, p. 164) observes that the response to the 2003 French heatwave ignored signals from outside 'convenient channels [or] in requested formats, lack[ed] a question-oriented culture' and, tragically, 'operat[ed] with a step-by-step, centralised and top-down approach'. After Hurricane Katrina, evacuation was slowed by bureaucratic requirements for air marshals and security screeners (Perrow, 2006). Emergency rations were confiscated in case they contained explosives, volunteer medics were turned away, as they were not licensed, and supplies were not despatched because they could not be requested in the required fax format. Bureaucrats clung, moreover, with resolute 'continuity' to stereotyped perceptions of black and poor people as criminals who needed control rather than support. 
Flexibility, however, requires accurate, real-time information-a problem for organisations with 'orderly', formally structured communication (Smallman and Weir, 1999). It requires open mental models, an ability to improvise, a shared conception of the overall system, willingness to question to interact respectfully (Weick, 1993). Groups must 'selforganise' in ad hoc networks (Weiss et al., cited in Kendra and Wachtendorf, 2003). Comfort (2002, p. 101), indeed, identifies a narrow region on 'the edge of chaos, where there is sufficient structure to hold and exchange information and sufficient flexibility to adapt to changing conditions'.

In this context, junior staff must 'carry out critical organisational tasks without close supervision' (Corbacioglu and Kapucu, 2006, p. 215). Against procedure and protocol, they may need to take charge, without formal authority, "flattening" ... formal hierarchy' (Superamaniam and Dekker, 2003, p. 314). In contrast to 'continuity', therefore, what is required is 'ambivalence to past practice' (Weiss et al., cited in Kendra and Wachtendorf, 2003, p. 42, emphasis added). Officials need to digest the wider context-beyond their own organisational interests, policies and practices including, above all, the suffering of others (Molotch, 2005). They must also be confident that others, including superiors, will also see this 'bigger picture'. Overall (Molotch, 2005, p. 2), 'unprecedented action requires ... a kind of panic of empathy that trumps organizational habit and individual postures'. It is clearly a matter of concern, when flexibility is crucial, if, as one practitioner put it in evidence to the Social Work Task Force:

The essence of a profession is when people make their own judgements and decisions... We've taken this out of social work. We have given it a very managerial focus. We've taken away some of the capacity of social workers to think for themselves (Social Work Task Force, 2009b, p. 32).

\section{Inter-organisational factors}

\section{Communication, co-ordination and co-operation}

Major incidents 'give[] rise to... incident organisation[s];... temporary configuration[s] of otherwise disparate resources drawn from many agencies' (Smith and Dowell, 2000, p. 1154). The dangers of non-co-operation and poor co-ordination are well rehearsed in crisis literatures. But, recent incidents suggest, difficulties have not been resolved through guidance (Davis, 2011). 'Co-ordination' itself is ambiguous. It may be interpreted as mutual agreement or as the direction of activities by one of the parties (Hills, 1994a). The danger in the latter case is that lack of corrective feedback within the broader 'incident organisation' allows mistakes to develop unchecked. 'Cosiness' can lead to a tactful avoidance of errors. 'Polite interaction,' Smithson notes (1990, p. 225), 'trades on vagueness, ambiguity, non-specificity, and even distortion.' 'An environment in which cooperation and feedback can thrive' (Hills, 1994b, p. 8) requires respectful 
interaction, in which information from others is taken seriously, reporting is honest and individuals integrate their own perspectives with those of others (Weick, 1993). Fundamentally, there is the need to avoid the wishful thinking involved in framing crisis as trending inevitably towards consensus, divorced somehow from pre-disaster inequality and conflict (Tierney, 2007). Rather, 'continuity' implies the continuing pervasiveness of social change, power and conflict at all levels (Henry, 2011).

Pressure towards consensus may be particularly problematic when there is an impetus towards control. Fears over security and disorder can overemphasise central authority, perimeter security and information control. Alexander (2002, p. 210) warns that 'civil defence [can] become ... an instrument of repression, subtle or otherwise in character' and left unchecked, security and bureaucratic priorities may lead to the subordination of victims' rights. In the UK, this was exemplified after the Lockerbie, Hillsborough, Marchioness and Dunblane disasters (Coleman et al., 1990; Davis and Scraton, 1999; North, 2000). More recently, when disaster survivors were accommodated at police headquarters, some CSWs felt that 'care' effectively became a form of 'detention' (Davis, 2011). Further afield, after Hurricane Katrina, The Army Times reported that 'combat operations are now underway on the streets.... This place is going to look like little Somalia.... We're going to go out and take the city back' (cited in Dynes and Rodriguez, 2005, p. 2, emphasis added). Two days later, with victims dying and with tens of thousands still awaiting rescue, officials proclaimed the establishment of a temporary centre to charge criminals (Kaufman, 2005, p. 1).

These should not be surprising outcomes where security and investigation are not counterbalanced. Police commonly assume 'lead' status in 'normal' work and guidance confirms the pre-eminence of the police in UK emergencies: co-ordinating other agencies, securing sites, recording evidence and processing casualty information (Civil Contingencies Secretariat, 2007). Police now also have important roles in Survivor Reception Centres, Family and Friends Reception Centres and Humanitarian Assistance Centres, where they will 'tend to be the initial point of contact' (HM Government, 2007, p. 24). What is needed is an enhanced appreciation of 'interagency checks and balances' (Rosenthal et al., 1991, p. 213), involving the management rather than the suppression of conflict. Given the extensive powers now available under the 2004 Civil Contingencies Act, CSTs need to apply 'traditional' social work values to ensure the salience of humanitarian priorities.

\section{Psychosocial response: integration and fragmentation}

Whilst there are dangers that agencies may become too close, it is notable that responsibility for the psychosocial tasks of the aftermath has become, 
in some ways, fragmented. Hospitals may no longer have the same familiarity with social work and social workers that they once had. After one emergency, a manager cited a 'nightmare' relationship between hospital and local authority. She rued the passing of 'traditional' hospital social work teams that had 'respond[ed] to things like road crashes ... as part of the hospital staff' and were experienced with loss, trauma and hospital procedures (Personal Interview, Crisis Support Manager, 2007). Now, she suggested, CSWs enter hospitals as strangers (Davis, 2011).

Two recent developments are worth comment: the deployment of police Family Liaison Officers (FLOs) and corporate Incident Care Teams (ICTs). The 1999 Ladbroke Grove train crash saw the first large-scale FLO deployment after disaster (Harrison, 2000). Their performance was considered by Clarke (2001), whose recommendations consolidated their emergency role. Successful crisis support now depends heavily on relationships between CSWs and FLOs. However, the FLO intervention at Ladbroke Grove was problematic:

FLOs were unsure of the role of social services, who were in turn equally unsure of the roles and functions of the FLOs. Both groups had no knowledge of ICAS, the counselling organisation nominated by the [Train Operating Companies].... It was clearly not the remit of the FLOs to counsel individuals, and both the social workers and a number of the ICAS counsellors made it clear that they were not bereavement counsellors. Initially there was no support available to those relatives dealing with bereaved children (Harrison, 2000, p. 3).

Working relationships must be forged before incidents. In one authority, CSWs and FLOs work in partnerships, jointly facilitating death notification, body viewings and site visits (Davis, 2011). Such partnerships are not, however, simply wished into existence. CSWs and FLOs train, exercise and work together on 'minor' emergencies (Davis, 2011). Even where successful, however, such partnerships raise issues of which CSWs should be cognisant. First, roles can become confused. After Ladbroke Grove, social workers were said to be 'reluctant to initiate early contact with the families as they felt their role was unclear, and to an extent superseded by the role of the FLOs' (Harrison, 2000, p. 4). Family liaison is, further, primarily an investigative role (Interview with Metropolitan Police Officers, 2007). Close partnerships might actually deter victims who are apprehensive about the 'authorities' from accessing support (Davis, 2011). Migrant or 'suspect' status, for example, will be of interest to police and immigration authorities. Police regard survivors', relatives' or witnesses' disclosures to partner agencies as potential evidence and/or intelligence and argue that there can be 'no absolute guarantee of confidentiality' (Interview with Metropolitan Police Officers, 2007). The idea of 'covert' use of a family liaison 'cover' by anti-terrorism officers has raised debate among police themselves (Interview with Metropolitan Police Officers, 2007). 
A second issue concerns the politics of blame. Fairly or otherwise, some responders may be implicated in causing, failing to prevent, or responding inadequately to incidents. FLOs in an interesting position may be required to investigate, support victims and manage image. Potential conflicts of interest here pre-date the emergence of the FLO. After the 1989 Marchioness disaster, police pressed one mother to keep secret her chance discovery that her daughter's hands had been severed in the post-mortem on the grounds that this was a 'one-off' mistake and that disclosing it would cause distress to others (Davis and Scraton, 1997). In fact, the hands had been cut from twenty-five of the dead (Clarke, 2001). More recently, the family of Ian Tomlinson, who died after being pushed to the ground by a police officer during the 2008 G20 protests, have argued that they were 'managed' according to police interests by their FLO (Lewis, 2009).

Another significant innovation, Corporate Incident Care Teams (ICTs) often have access to significant resources (Davis, 2011). There are, however, potential issues here around corporations' involvement after incidents in which they may have been complicit. Social workers have complained, too, that FLO access to ICT resources diminished their own roles (Harrison, 2000). This raises the possibility of public sector responders scrambling for resources for victims, dispensed by-potentially-the 'corporate criminal'. It is unclear, moreover, how ICTs come to an understanding of the local system of which they suddenly become parts. ICT workers usually represent national or international corporations and it remains to be seen whether they will participate fully in local planning and preparation. Experience of local officials in one recent incident was mixed (Davis, 2011). On the one hand, ICT funds facilitated the meeting of practical needs. On the other, valuable CST time had to be spent orienting the team, both geographically and in terms of role.

\section{Conclusion}

Crisis support operates within highly challenging contexts. Disasters require reflexive and imaginative assessment and success depends upon a range of organisational factors: capacity, continuity and flexibility. Yet, resources are tight, social work, according to many is becoming de-skilled in key areas and its bureaucratised nature is unlikely to encourage the devolution of authority to front line staff. Whilst 'co-ordination' and 'cooperation' are generally exhorted, building and maintaining relationships requires time, commitment and resources. It also requires, the continuity principle suggests, regular interaction in 'normal' work (or as an alternative in 'minor' emergencies). The imperatives of co-ordination and 'partnership' are themselves problematic, understating the risks of 'cosiness' and the importance of corrective checks and balances. On the other hand, support can 
become fragmented. Local authorities must integrate new partners into responses even where they have not participated in preparations. The unpredictability of which organisations might actually be involved only emphasises the importance of robust local arrangements.

Whilst this article outlines problems, some suggestions can be made. Nationally, the cursory attention paid to crisis support in guidance should be rectified and consider the significance of changes within social work and between it and its partners. Local authorities should realistically appraise the recruitment, training and practice opportunities for potential CSWs. Fairly obvious questions suggest themselves. How can sufficient staff be recruited, motivated and retained? How will their 'everyday' workloads be managed, before or after incidents? Will their everyday work equip them for disaster? Are they capable of, and trusted in, working outside of familiar procedures? Perhaps most crucially, how are humanitarian priorities to be most reliably secured amid multi-agency responses within which security often dominates. Effective inter-agency response is the most difficult challenge posed by unforeseen events. 'Success' requires sustained investment in establishing, maintaining and renewing such relationships at all levels.

A central issue throughout this article is 'continuity'. At the organisational level, responders need to be familiar with the type of challenges they will face, with their roles and with each other, before disaster. One interesting option is to deploy CSTs at minor incidents. One authority recently deployed teams at over thirty such incidents over three years (Davis, 2011). Landslips, hostage situations, floods, explosions, evacuations and traffic collisions were the diet on which they cut their teeth. Continuity here was established less with the 'everyday' work of social workers as with their regular CSW interventions in minor emergencies. At a broader level, continuity does not imply 'a neo-functionalist view of disasters as consensus builders ... [rather it is] ... closely connected to issues of social change and power played out at the micro- and macrosocial levels' (Henry, 2011, p. 221). Harm and victimisation in disaster and its aftermath (sometimes at the hands of official agencies) do not stand apart from broader organisational and structural contexts (see, e.g. Lagadec, 2004; Ramon, 2004; Tucker, 2004; Dynes and Rodriguez, 2005; Kaufman, 2005; Lukes, 2005; Davis, 2007; Scraton, 2007; Henry, 2011). Rather, it may be at just the point of disaster's impact that victims need skilled, knowledgeable and powerful advocates for their needs and their rights. The key questions concern whether the predisaster knowledge, practices, policies and cultures with which would-be CSWs are presently familiar are likely to equip them for this role. The concern must be, especially given the mounting evidence of an increasingly bureaucratised UK social work in crisis, an emergency environment increasingly dominated by imperatives of security, and the fragmentation of psycho-social responses, that they may not. 


\section{References}

Alexander, D. (2002) 'From civil defence to civil protection - and back again', Disaster Prevention and Management, 11(3), pp. 209-13.

Benoit, W. L. (1997) 'Image repair and crisis communication', Public Relations Review, 23(2), pp. 177-86.

Berger, B. K. (1999) 'The halcion affair: Public relations and the construction of ideological world view', Journal of Public Relations Research, 11(3), pp. 185-203.

Birkland, T. A. (2004) "“The world changed today": Agenda-setting and policy change in the wake of the September 11 terrorist attacks', Review of Policy Research, 21(3), pp. 179-200.

Birkland, T. A. and Nath, R. (2000) 'Business and political dimensions in disaster management', Journal of Public Policy, 20(3), pp. 275-303.

Bisson, J. I., Brayne, M., Ochberg, F. M. and Everly, G. S. (2007) 'Early psychosocial intervention following traumatic events', American Journal of Psychiatry, 164(7), pp. 1016-19.

Blaug, R. (1995) 'Distortion of the face to face: Communicative reason and social work practice', British Journal of Social Work, 25(4), pp. 423-39.

Cabinet Office (2007) Responding to Emergencies: Draft Guidance on Response to and Recovery from Emergencies: The Proposed Replacement for 'Dealing with Disaster', Cabinet Office/Civil Contingencies Secretariat, available online at www.ukresilience.info/upload/ assets/www.ukresilience.info/responding.pdf (accessed on 12 April, 2007).

Carey, M. (2008a) 'Everything must go? The privatization of social work', British Journal of Social Work, 38(5), pp. 918-35.

Carey, M. (2008b) 'The quasi-market revolution in the head', Journal of Social Work, 8(4), pp. 341-62.

Civil Contingencies Secretariat (2007) Emergency Response and Recovery: Non-Statutory Guidance to Complement Emergency Preparedness, London, HM Government.

Clarke, L. J. (2001) Marchioness/Bowbelle: Formal Investigation under the Merchant Shipping Act 1995, Vol. 1, London, The Stationery Office.

Coleman, S., Jemphrey, A., Scraton, P. and Skidmore, P. (1990) Hillsborough and After: The Liverpool Experience First Report, Liverpool, Liverpool City Council.

Comfort, L. (2002) 'Rethinking security: Organizational fragility in extreme events', Public Administration Review, 62, pp. 98-107.

Comfort, L., Sungu, Y., Johnson, D. and Dunn, M. (2001) 'Complex systems in crisis: Anticipation and resilience in dynamic environments', Journal of Contingencies and Crisis Management, 9(3), pp. 144-58.

Corbacioglu, S. and Kapucu, N. (2006) 'Organisational learning and adaptation in dynamic disaster environments', Disasters, 30(2), pp. 212-33.

Davis, H. (2007) 'Taking crime seriously? Disaster, victimization and justice', in A. Barton, K. Corteen, D. Scott and D. Whyte (eds), Expanding the Criminological Imagination, Cullompton, Willan, pp. 136-67.

Davis, H. (2011) 'A critical evaluation of crisis support arrangements in a UK local authority', Journal of Contingencies and Crisis Management, 19(3), pp. 124-35.

Davis, H. and Scraton, P. (1997) Beyond Disaster: Identifying and Resolving Inter-Agency Conflict in the Immediate Aftermath of Disasters, Research Report for the Home Office Emergency Planning Division, Ormskirk, Centre for Studies in Crime and Social Justice. 
Davis, H. and Scraton, P. (1999) 'Institutionalised conflict and the subordination of "loss" in the immediate aftermath of UK mass fatality disasters', Journal of Contingencies and Crisis Management, 7(2), pp. 86-97.

Davis, T. (2006) A Failure of Initiative: The Final Report of the Select Bipartisan Committee to Investigate the Preparation for and Response to Hurricane Katrina, Washington, US House of Representatives, available online at www.katrina.house.gov/.

Dekel, R. and Baum, N. (2010) 'Intervention in a shared traumatic reality: A new challenge for social workers', British Journal of Social Work, 40(6), pp. 1927-44.

Dominelli, L. and Hoogvelt, A. (1996) 'Globalization and the technocratization of social work', Critical Social Policy, 47(16), pp. 45-62.

Dumfries and Galloway (1989) Lockerbie Air Disaster: The Social Work Response, Dumfries and Galloway, Regional Council of Social Work.

Dynes, R. (1994) 'Community emergency planning: False assumptions and inappropriate analogies', International Journal of Mass Emergencies and Disasters, 12, pp. 141-58.

Dynes, R. and Rodriguez, H. (2005) 'Finding and framing Katrina: The social construction of disaster', Understanding Katrina: Perspectives from the Social Sciences, available online at http://understandingkatrina.ssrc.org/Dynes_Rodriguez/.

Ferguson, I. and Lavalette, M. (2004) 'Beyond power discourse: Alienation and social work', British Journal of Social Work, 34(3), pp. 297-312.

Green, R., Bates, L. and Smyth, A. (2007) 'Impediments to recovery in New Orleans' Uppers and Lower Ninth Ward: One year after Hurricane Katrina', Disasters, 31(4), pp. 311-35.

Harrison, R. (2000) 'The Ladbroke rail crash: Analysis of the support requested by bereaved families and survivors in the immediate aftermath', in L. J. Clarke (2001) Public Inquiry into the Identification of Victims Following Major Transport Accidents, Vol. 2, Appendix J, Norwich, The Stationery Office.

Henry, J. (2011) 'Continuity, social change and Katrina', Disasters, 35(1), pp. 220-41.

Hills, A. (1994a) 'Co-ordination and disaster response in the United Kingdom', Disaster Prevention and Management, 3(1), pp. 66-71.

Hills, A. (1994b) 'Myth and method: Co-ordination and co-operation in disaster management', Disaster Management, 6(1), pp. 3-8.

HM Government (2005) Emergency Preparedness: Guidance on Part 1 of the Civil Contingencies Act 2004, Its Associated Regulations and Non-Statutory Arrangements, available online at www.ukresilience.info/upload/assets/www.ukresilience.info/ emergprepfinal.pdf (accessed on 12 April, 2007).

HM Government (2006) Emergency Response and Recovery: Non-Statutory Guidance to Complement 'Emergency Preparedness', available online at www.ukresilience.info/ ccact/errpdfs/emergresponse.pdf (accessed on 9 November 2006).

HM Government (2007) Humanitarian Assistance in Emergencies: Non-Statutory Guidance on Establishing Humanitarian Assistance Centres, available online at www.ukresilience. info/upload/assets/www.ukresilience.info/hac_guidance.pdf (accessed on 8 September 2007).

Hodgkinson, P. E. and Stewart, M. (1991) Coping with Catastrophe: A Handbook of Disaster Management, London, Routledge.

Horner, K. (1998) The Estonia Ferry Disaster, 28th September 1994, Course Handout, Home Office Emergency Planning College, Easingwold, York.

Johnes, M. (2000) 'Aberfan and the management of trauma', Disasters, 24(1), pp. 1-17. 
Johnston, J. and Beeson, L. (1993) 'Social work in the aftermath of the Zeebrugge ferry disaster', in T. Newburn (ed.), Working with Disaster: Social Welfare Intervention During and After Tragedy, Harlow, Longman, pp. 65-75.

Kaufman, S. (2005) 'The criminalization of New Orleanians in Katrina's wake', Understanding Katrina: Perspectives from the Social Sciences, available online at http:// understandingkatrina.ssrc.org/Kaufman/.

Kendra, J. M. and Wachtendorf, T. (2003) 'Elements of resilience after the World Trade Center disaster: Reconstituting New York City's Emergency Operations Centre', Disasters, 27(1), pp. 37-53.

Lagadec, P. (2004) 'Understanding the French Heat Wave experience: Beyond the heat, a multi-layered challenge', Journal of Contingencies and Crisis Management, 12(4), pp. 160-9.

Lennquist, S. (2004) 'The Tsunami disaster: New lessons learned and old lessons to be learned better', International Journal of Disaster Medicine, 2, pp. 71-3.

Lewis, P. (2009) 'Memos reveal how police investigated Ian Tomlinson's death at G20 protests', The Guardian, available online at www.guardian.co.uk/uk/2009/aug/07/ ian-tomlinson-death-police-memos.

Lukes, S. (2005) 'Questions about power: Lessons from the Louisiana Hurricane', Understanding Katrina: Perspectives from the Social Sciences, available online at http:// understandingkatrina.ssrc.org/Lukes/.

Malkinson, R. (2003) 'Battling the Black Sea despair: Cross-cultural consultation following and air disaster', Journal of Loss and Trauma, 8(2), pp. 99-113.

Medd, W. and Marvin, S. (2005) 'From the politics of urgency to the governance of preparedness: A research agenda on urban vulnerability', Journal of Contingencies and Crisis Management, 13(2), pp. 44-53.

Molotch, H. (2005) 'Death on the roof: Race and bureaucratic failure', Understanding Katrina: Perspectives from the Social Sciences, available online at http:// understandingkatrina.ssrc.org/\%3Colotch/.

Munro, E. (2004) 'The impact of audit on social work practice', British Journal of Social Work, 34(8), pp. 1075-95.

Newburn, T. (1993) Making a Difference? Social Work after Hillsborough, London, National Institute for Social Work.

North, M. (2000) Dunblane: Never Forget, Edinburgh, Mainstream.

Olejarski, A. M. and Garnett, J. L. (2010) 'Coping with Katrina: Assessing crisis management behaviours in the big one', Journal of Contingencies and Crisis Management, 18(1), pp. 26-38.

Parton, N. (2008) 'Changes in the form of knowledge in social work: From the "social" to the "informational"?', British Journal of Social Work, 38(2), pp. 253-69.

Perrow, C. (2006) 'Using organisations: The case of FEMA', Understanding Katrina: Perspectives from the Social Sciences, available online at http://understandingkatrina.ssrc. org $/ \% 3$ Colotch $/$.

Pollack, S. (2010) 'Labelling clients as "risky": Social work and the neo-liberal welfare state', British Journal of Social Work, 40(4), pp. 1263-78.

Ramon, S. (2004) 'The impact of the Second Intifada on Israeli Arab and Jewish social workers', European Journal of Social Work, 7(3), pp. 285-303.

Rosenthal, U. and Kouzmin, A. (1996) 'Crisis management and institutional resilience: An editorial statement', Journal of Contingencies and Crisis Management, 4(3), pp. 119-24. 
Rosenthal, U., 't Hart, P., van Duin, M., Boin, A., Kroon, M., Otten, M. and Overdijk, W. (1994), Complexity in Urban Crisis Management: Amsterdam's Response to the Bijlmer Air Disaster, London, James and James.

Rosenthal, U., 't Hart, P. and Kouzmin, A. (1991) 'The Bureau-Politics of Crisis Management', Public Administration, 69, Summer, pp. 211-33.

Scott, M. J. and Stradling, S. B. J. (1992) Counselling for Post Traumatic Stress Disorder, London, Sage.

Scraton, P. (1995) No Last Rights: The Denial of Justice and the Promotion of Myth in the Aftermath of the Hillsborough Disaster, Oxford, Alden Press.

Scraton, P. (1999) Hillsborough the Truth, Edinburgh, Mainstream.

Scraton, P. (2007) 'Negligence without liability: The scale of injustice after Hillsborough', in P. Scraton (ed.), Power, Conflict and Criminalisation, Abingdon, Routledge.

Sellnow, T. L., Seeger, M. W. and Ulmer, R. R. (2002) 'Chaos theory, informational needs, and natural disasters', Journal of Applied Communication Research, 30(4), pp. 269-92.

Smallman, C. and Weir, D. (1999) 'Communication and cultural distortion during crises', Disaster Prevention and Management, 8(1), pp. 33-41.

Smith, J. (2003) 'Civil contingency planning in government', Parliamentary Affairs, 56(3), pp. $410-22$.

Smith, M., Lees, D. and Clymo, K. (2003) 'The readiness is all: Planning and training for post disaster support work', Social Work Education, 22(5), pp. 517-28.

Smith, W. and Dowell, J. (2000) 'A case study of co-ordinative decision making in disaster management', Ergonomics, 43(8), pp. 1153-66.

Smithson, M. (1990) 'Ignorance and disasters', International Journal of Mass Emergencies and Disasters, 8(3), pp. 207-35.

Social Work Task Force (2009a) Building a Safe, Confident Future: The Final Report of the Social Work Task Force?, Department of Health/Department for Children, Schools and Families, available online at https://www.education.gov.uk/publications/ eOrderingDownload/01114-2009DOM-EN.pdf.

Social Work Task Force (2009b) Facing Up to the Task: The Interim Report of the Social Work Task Force?, Department of Health/Department for Children, Schools and Families, available online at https://www.education.gov.uk/publications/ eOrderingDownload/DCSF-00752-2009.pdf.

Superamaniam, N. and Dekker, S. (2003) 'Paradoxes of power: The separation of knowledge and authority in international disaster relief work', Disaster Prevention and Management, 12(4), pp. 312-18.

Tierney, K. J. (2007) 'From the margins to the mainstream? Disaster research at the crossroads', Annual Review of Sociology, 33, pp. 503-25.

Tucker, J. (2004) 'Making difference in the aftermath of the September 11th terrorist attacks', Critique of Anthropology, 24(1), pp. 34-50.

Tyler, L. (2005) 'Towards a postmodern understanding of crisis communication', Public Relations Review, 31(4), pp. 566-71.

Weick, K. E. (1993) 'The collapse of sensemaking in organisations: The Mann Gulch disaster', Administrative Science Quarterly, 38(4), pp. 628-52. 